\title{
PENGARUH PEMBERIAN KOMPOS KULIT BUAH KAKAO SEBAGAI CAMPURAN MEDIA PEMBIBITAN DAN PUPUK NPK (15:15:15) TERHADAP PERTUMBUHAN BIBIT KAKAO (Theobroma cacao L.)
}

\author{
Minarsih, M. A. Syamsul Arif, Maria Viva Rini \& Rusdi Evizal \\ Jurusan Agroteknologi, Fakultas Pertanian Universitas Lampung \\ Jl. Prof. Soemantri Brodjonegoro, No.1, Bandar Lampung 35145 \\ E-mail: minarsihminz@ymail.com
}

\begin{abstract}
ABSTRAK
Media tanam merupakan salah satu faktor yang mempengaruhi pertumbuhan tanaman kakao di pembibitan. Kompos kulit buah kakao berpotensi sebagai campuran media pembibitan kakao. Pemberian pupuk NPK sebagai tambahan unsur hara makro ke media pembibitan dapat meningkatkan pertumbuhan bibit kakao. Penelitian dilakukan untuk mengetahui: (1) berapakah dosis kompos kulit buah kakao yang menghasilkan pertumbuhan bibit kakao terbaik, (2) berapakah dosis pupuk NPK yang menghasilkan pertumbuhan bibit kakao terbaik dan (3) berapakah kombinasi dosis pupuk NPK dan kompos kulit buah kakao yang menghasilkan pertumbuhan bibit tanaman kakao terbaik. Penelitian dilaksanakan di Rumah Kaca Fakultas Pertanian Universitas Lampung pada Desember 2011-September 2012. Rancangan perlakuan disusun sacara faktorial dengan empat ulangan. Faktor pertama adalah dosis campuran kompos kulit buah kakao (K) dengan tiga taraf: 0\%, 12,5\% dan 25,0\% (v/v). Faktor kedua adalah pupuk NPK (P) dengan empat taraf: 1,5; 3,0; 4,5; dan 6,0 (g/tanaman). Hasil penelitian menunjukkan bahwa perlakuan tanpa kompos kulit buah kakao menghasilkan pertumbuhan bibit kakao terbaik tetapi tidak berbeda nyata dengan pemberian kompos kulit buah kakao sebanyak 12,5\%. Pemupukan NPK 1,5 g/tanaman menghasilkan pertumbuhan bibit kakao terbaik. Pemberian dosis pupuk NPK sebanyak 1,5; 3,0; dan 6,0 g/tanaman yang dikombinasikan dengan kompos $0 \%(\mathrm{v} / \mathrm{v})$ menghasilkan pertumbuhan bibit tanaman kakao terbaik.
\end{abstract}

Kata kunci: kakao, kompos kulit buah kakao, pupuk NPK

\section{PENDAHULUAN}

Tanaman kakao (Theobroma cacao L.) merupakan salah satu tanaman perkebunan yang memiliki prospek baik. Provinsi Lampung telah mengembangkan tanaman kakao sebagai komoditas unggulan dalam menghasilkan devisa negara melalui kegiatan ekspor komoditi perkebunan kakao.

Pembibitan merupakan salah satu faktor dalam menentukan keberhasilan budidaya tanaman kakao. Media tanam yang umum digunakan dalam pembibitan adalah media tanah atau media tanah yang diberi bahan organik. Salah satu limbah pertanian yang baru sedikit dimanfaatkan sebagai bahan organik adalah limbah dari perkebunan kakao yaitu kulit buah kakao. Spillane (1995) mengemukakan bahwa kulit buah kakao dapat dimanfaatkan sebagai sumber unsur hara tanaman dalam bentuk kompos, pakan ternak, produksi biogas dan sumber pektin. Penambahan kompos kulit buah kakao merupakan upaya untuk meningkatkan kualitas fisik, biologi, dan kimia media tumbuh tanaman.

Sifat fisik yang dapat diperbaiki oleh kompos kulit buah kakao yaitu struktur media tanam yang digunakan akan menjadi lebih gembur. Sifat biologi yang dapat diperbaiki dengan adanya kompos kulit buah kakao yaitu menambah pasokan energi yang diperlukan mikroorganisme tanah, sehingga dapat mempercepat pelepasan unsur hara yang belum terurai di media tanam. Sifat kimia yang dapat diperbaiki dengan adanya kompos kulit buah kakao yaitu meningkatkan kapasitas tukar kation (KTK) dan C-organik serta mampu memperbaiki pH media tanam. Menurut Mensah et al. (2012), kekurangan kulit buah kakao adalah memiliki sifat antinutrisi akibat kandungan senyawa tanin yang dapat mengikat berbagai macam enzim digestif sehingga enzim tersebut menjadi tidak efektif.

Menurut Didiek dan Away (2004), bokashi kulit buah kakao mempunyai pH 5,4; $\mathrm{N}$ total 1,30\%; C-organik $33,71 \% ; \mathrm{P}_{2} \mathrm{O}_{5} 0,186 \%$; $\mathrm{K}_{2} \mathrm{O} 5,5 \%$; $\mathrm{CaO} 0,23 \%$; dan $\mathrm{MgO} 0,59 \%$. Kandungan hara yang dimiliki kompos kulit buah kakao relatif rendah, sehingga perlu adanya penambahan unsur hara dalam media tanam. Sutejo (2002) menyatakan bahwa pemberian pupuk anorganik ke dalam tanah dapat menambah ketersediaan hara yang cepat bagi tanaman.

Pemberiaan pupuk NPK pada pembibitan kakao dimaksudkan menambah ketersediaan unsur hara N, P, dan $\mathrm{K}$ sehingga ketersediaanya lebih terjamin dan 
diharapkan dapat meningkatkan pertumbuhan bibit kakao.

Nitrogen berperan dalam pembentukan zat hijau daun (klorofil) dan protein dalam tanaman. Fosfor berfungsi untuk merangsang pembelahan sel tanaman dan kalium berperan dalam meningkatkan daya tahan/ kekebalan tanaman. Peranan dari ketiga unsur tersebut akan menghasilkan pertumbuhan bibit tanaman yang maksimum jika diberikan dengan dosis yang tepat.

Penelitian ini bertujuan untuk mengetahui dosis kompos kulit buah kakao yang menghasilkan pertumbuhan bibit kakao terbaik, berapakah dosis pupuk NPK yang menghasilkan pertumbuhan bibit kakao terbaik, dan kombinasi dosis pupuk NPK dan kompos kulit buah kakao yang menghasilkan pertumbuhan bibit tanaman kakao terbaik.

\section{BAHAN DAN METODE}

Penelitian dilaksanakan pada Desember 2011September 2012 di Rumah Kaca Kampus Gedong Meneng Fakultas Pertanian Universitas Lampung, Bandar Lampung. Penelitian ini menggunakan rancangan perlakuan faktorial $(3 \times 4)$ yang disusun dalam rancangan acak kelompok (RAK) dengan empat ulangan. Faktor pertama adalah volume kompos kulit buah kakao dalam media tanam dengan tiga taraf yaitu $0 ; 12,5$ dan 25,0 \% (v/v). Faktor kedua adalah dosis pupuk majemuk NPK (P) dengan empat taraf yaitu 1,5 ; 3,$0 ; 4,5$ dan 6,0 (g/tanaman). Uji homogenitas dengan uji $\chi^{2}$ dan additifitas data diuji dengan uji Tukey. Analisis data dilanjutkan dengan menggunakan analisis ragam dan uji pemisahan nilai tengah dengan Uji Beda Nyata Jujur (BNJ) pada taraf nyata 5\%.

Limbah kulit buah kakao dalam penelitian ini didapatkan dari PT Pluit Muda Lestari di Desa Bernung Kecamatan Gedong Tataan, Kabupaten Pesawaran. Limbah ini terlebih dahulu dicacah dengan mesin pencacah kulit kakao berukuran $\pm 2-5 \mathrm{~cm}$ dan menghasilkan $+300 \mathrm{~kg}$ cacahan basah kulit buah kakao. Kemudian hasil cacahan dimasukkan ke dalam kotak pengomposan lalu disiram dengan larutan EM4 dan diaduk. Dosis EM4 yang digunakan sebanyak $80 \mathrm{ml}$ EM4 dilarutkan dengan gula merah 300 gram dalam 20 liter air. Setelah itu, kotak pengomposan ditutup dengan plastik dan dilakukan pengadukan setiap minggu selama proses pengomposan berjalan. Kompos kulit buah kakao siap digunakan apabila rasio $\mathrm{C} / \mathrm{N} \leq 20$ dengan ciri-ciri tidak berbau, berwarna gelap (hitam), tidak lengket, dan bertekstur remah. Setelah ciri tersebut diperoleh dilakukan pengayakan kompos sebelum diaplikasikan sebagai campuran media tanam. Hasil analisis kompos kulit buah kakao yang sudah matang adalah sebagai berikut: $\mathrm{pH} 7,22 ; \mathrm{N}$-total 0,61\%; P-total 3,0\%; C-organik 10,02 dan $\mathrm{C} / \mathrm{N}$ rasio $16,61 \%$.

Benih kakao terlebih dahulu dibersihkan dari lendir dengan menggunakan pasir. Benih kakao varietas hibirida TSH 858 ini berasal dari PTPN VII Kabupaten Pesawaran. Benih yang sudah siap, ditanam pada pre nursery di dalam bak penyemaian dengan media tanam berupa pasir steril. Semaian dipelihara sampai benih berumur \pm 14 hari. Penyiraman dilakukan 2 kali sehari menggunakan gembor.

Media tanam berupa campuran kompos kulit buah kakao dan tanah berpasir (1:1) disiapkan dengan cara memasukkan kompos kulit buah kakao dan tanah berpasir sesuai dengan perbandingan volume perlakuan. Semaian kakao yang sudah berumur \pm 14 hari dipindah tanam ke polibag. Semaian dipilih yang seragam, bervigor, sehat, akarnya lurus dan tidak mengalami kerusakan. Setiap polibag $( \pm 2 \mathrm{~kg})$ yang sudah berisi media tanam yaitu campuran kompos kulit buah kakao dan tanah berpasir ditanami satu bibit kakao. Masing-masing perlakuan diwakili dua bibit kakao.

Pemberian pupuk dilakukan dengan membuat lingkaran dengan jarak $\pm 4 \mathrm{~cm}$ dari batang tanaman. Setelah pupuk diberikan kemudian pupuk tersebut ditutupi dengan media tanam. Pada umur 1 BST diberikan setengah dosis perlakuan dan sisanya di umur 3 BST. Pemeliharaan tanaman meliputi kegiatan penyiraman dan penyiangan gulma.

Pengamatan tinggi tanaman $(\mathrm{cm})$ dilakukan dengan menggunakan mistar yaitu diukur dari pangkal batang sampai daun terpanjang. Pengamatan tanaman dilakukan 1 BST sampai penelitian berakhir selama 4 BST setiap satu bulan.

Pengamatan jumlah daun (helai) dilakukan dengan menghitung jumlah daun yang sudah membuka sempurna setiap tanaman secara manual. Pengukuran ini dilakukan 1 BST sampai penelitian berakhir selama 4 BST setiap satu bulan.

Pengamatan bobot basah akar (g) dilakukan di akhir pengamatan penelitian, dengan memisahkan bagian akar tanaman dan langsung ditimbang dengan timbangan digital.

Pengamatan bobot kering tajuk dan akar (g). Pengukuran dilakukan di akhir penelitian, tajuk dan akar tanaman dipisahkan kemudian dimasukkan oven dengan suhu $70^{\circ} \mathrm{C}$ hingga bobotnya konstan dan ditimbang.

\section{HASIL DAN PEMBAHASAN}

Hasil rekapitulasi analisis ragam menunjukkan bahwa pemberian kompos kulit buah kakao berpengaruh 
nyata pada semua variabel yang diamati. Pemberian peningkatan pupuk NPK berpengaruh nyata pada bobot kering akar. Terdapat interaksi antara pemberian kompos kulit buah kakao dan pupuk NPK terhadap jumlah daun dan bobot basah akar (Tabel 1). Perlakuan kontrol dan kompos 12,5\% (v/v) menghasilkan tinggi tanaman, bobot kering tajuk dan bobot kering akar yang tidak berbeda nyata. Namun jika kompos ditingkatkan menjadi 25,0\% $(\mathrm{v} / \mathrm{v})$ secara nyata menghambat perkembangan tinggi tanaman (Tabel 2), bobot kering tajuk (Tabel 3) dan bobot kering akar (Tabel 4) tanaman kakao.

Pemberian kompos $25,0 \%(\mathrm{v} / \mathrm{v})$ yang diaplikasikan dengan pupuk NPK sebanyak 4,5 g/ tanaman menghasilkan jumlah daun terendah yaitu 12,8

Tabel 1. Rekapitulasi hasil analisis ragam pengaruh pemberian kompos kulit buah kakao sebagai media campuran pembibitan dan pupuk NPK terhadap pertumbuhan bibit kakao pada 4 bulan setelah transpalnting.

\begin{tabular}{lccc}
\hline \multirow{2}{*}{ Variabel pengamatan } & \multicolumn{3}{c}{ Signifikasi } \\
\cline { 2 - 4 } & Kompos kulit kakao (K) & Pupuk NPK (P) & K x P \\
\hline Tinggi tanaman & $* *$ & tn & tn \\
Jumlah daun & $* *$ & $* *$ & tn \\
Bobot kering tajuk & $* *$ & tn & $* *$ \\
Bobot basah akar & $* *$ & $* *$ & tn \\
Bobot kering akar & $* *$ & $* *$ & \\
\hline
\end{tabular}

Keterangan: $\operatorname{tn}=$ tidak nyata, ${ }^{*}=$ nyata pada $\alpha_{0,05}{ }^{* *}=$ nyata pada $\alpha_{0,01}$.

Tabel 2. Pengaruh kompos kulit buah kakao sebagai campuran pada media pembibitan terhadap tinggi tanaman kakao pada pengamatan $1 \mathrm{~s} / \mathrm{d} 4$ bulan setelah transplanting $(1 \mathrm{~s} / \mathrm{d} 4 \mathrm{BST})$

\begin{tabular}{ccccc}
\hline $\begin{array}{c}\text { Perlakuan } \\
\% \text { kompos }(\mathrm{v} / \mathrm{v})\end{array}$ & 1 BST & $2 \mathrm{BST}$ & $3 \mathrm{BST}$ & $4 \mathrm{BST}$ \\
\cline { 2 - 5 } & $36,4 \mathrm{~b}$ & $45,8 \mathrm{~b}$ & $56,2 \mathrm{~b}$ & $66,5 \mathrm{~b}$ \\
0,0 & $36,6 \mathrm{~b}$ & $44,5 \mathrm{~b}$ & $55,4 \mathrm{~b}$ & $64,0 \mathrm{~b}$ \\
25,5 & $33,2 \mathrm{a}$ & $41,2 \mathrm{a}$ & $47,6 \mathrm{a}$ & $53,0 \mathrm{a}$ \\
\hline BNJ 0,05 & 1,7 & 2,9 & 5,6 & 3,7 \\
\hline
\end{tabular}

Keterangan: Angka yang diikuti oleh huruf yang sama dalam satu kolom tidak berbeda nyata berdasarkan uji BNJ pada $\alpha_{0,05}$. BST = bulan setelah tanam.

Tabel 3. Pengaruh kompos kulit buah kakao sebagai campuran pada media pembibitan dan pupuk NPK terhadap bobot kering tajuk tanaman kakao

\begin{tabular}{cc}
\hline Perlakuan \% kompos $(\mathrm{v} / \mathrm{v})$ & Bobot kering tajuk $(\mathrm{g})$ \\
\hline 0,0 & $7,0 \mathrm{~b}$ \\
12,5 & $6,3 \mathrm{~b}$ \\
25,0 & $4,0 \mathrm{a}$ \\
\hline BNJ & 0,9 \\
\hline Pupuk NPK (g/tanaman) & Bobot kering tajuk $(\mathrm{g})$ \\
\hline 1,5 & 5,7 a \\
3,0 & $5,7 \mathrm{a}$ \\
4,5 & $5,4 \mathrm{a}$ \\
6,0 & $6,0 \mathrm{a}$ \\
\hline BNJ & 1,1 \\
\hline
\end{tabular}

Keterangan: Angka yang diikuti oleh huruf yang sama dalam satu kolom tidak berbeda nyata berdasarkan uji BNJ pada $\alpha_{0,05}$. 
helai umur 4 bulan setelah transplanting (BST) (Tabel 5). Pemberian kompos $0 \%$ (v/v) yang dikombinasikan dengan pupuk NPK sebanyak 1,5; 3,0; dan 6,0 g/tanaman menghasilkan rata-rata bobot basah akar tanaman kakao tertinggi. Pemberian peningkatan dosis pupuk NPK yang dikombinasikan dengan kompos 25,0\% (v/v) menurunkan bobot basah akar tanaman kakao tetapi tidak berbeda nyata dengan kombinasi pemberian kompos sebanyak $12,5 \%(\mathrm{v} / \mathrm{v})($ Tabel 6). Terdapat korelasi positif antara bobot kering akar dengan tinggi tanaman, jumlah daun, diameter batang, kandungan zat hijau daun dan bobot kering tajuk (Tabel 7).

Pemberian kompos kulit buah kakao sebanyak $25,0 \%(\mathrm{v} / \mathrm{v})$ di media tanam dapat menurunkan pertumbuhan bibit tanaman kakao. Penurunan pertumbuhan bibit kakao akibat

perlakuan kompos diduga karena adanya senyawa inhibitor (penghambat) berupa senyawa tanin yang terkandung di dalam kompos kulit buah kakao. Hal ini dapat dibuktikan pada saat penyiraman bibit tanaman kakao, air yang keluar dari polibag berwarna kecokelatan, warna tersebut sebagai indikator adanya kandungan senyawa tanin dalam media tanam. Kristijono (2010) menyatakan bahwa adanya zat tanin ditandai dengan keluarnya warna merah bata-cokelat pada saat serabut kelapa direndam oleh air. Menurut Green dan Corcoran (1975) yang dikutip oleh Primiadi dan Suyitno (2010), tanin menghambat aktivitas enzim

Tabel 4. Pengaruh kompos kulit buah kakao sebagai campuran pada media pembibitan dan pupuk NPK terhadap bobot kering akar tanaman kakao

\begin{tabular}{cc}
\hline Perlakuan \% kompos (v/v) & Bobot kering tajuk $(\mathrm{g})$ \\
\hline 0,0 & $1,04 \mathrm{~b}$ \\
12,5 & $0,85 \mathrm{~b}$ \\
25,0 & $0,59 \mathrm{a}$ \\
\hline BNJ & 0,22 \\
\hline Pupuk NPK (g/tanaman) & Bobot kering tajuk $(\mathrm{g})$ \\
\hline 1,5 & $1,03 \mathrm{~b}$ \\
3,0 & $0,77 \mathrm{a}$ \\
4,5 & $0,72 \mathrm{a}$ \\
6,0 & $0,79 \mathrm{a}$ \\
\hline BNJ & 0,28
\end{tabular}

Keterangan: Angka yang diikuti oleh huruf yang sama dalam satu kolom tidak berbeda nyata berdasarkan uji BNJ pada $\alpha_{0,05}$.

Tabel 5. Pengaruh kompos kulit buah kakao sebagai campuran pada media pembibitan dan pupuk NPK terhadap jumlah daun tanaman kakao pada pengamatan 4 bulan setelah transplanting (4 BST)

\begin{tabular}{ccccc}
\hline \multirow{2}{*}{$\%$ Kompos $(\mathrm{v} / \mathrm{v})$} & \multicolumn{5}{c}{ Pupuk NPK (g/tanaman) } \\
\cline { 2 - 5 } & 1,5 & 3,0 & 4,5 & 6,0 \\
\hline \multirow{5}{*}{0,0} & $17,3 \mathrm{a}$ & $18,6 \mathrm{a}$ & $17,1 \mathrm{a}$ & $17,9 \mathrm{a}$ \\
& $(\mathrm{A})$ & $(\mathrm{B})$ & $(\mathrm{B})$ & $(\mathrm{AB})$ \\
12,5 & $17,4 \mathrm{a}$ & $17,6 \mathrm{a}$ & $18,6 \mathrm{a}$ & $18,6 \mathrm{a}$ \\
& $(\mathrm{A})$ & $(\mathrm{AB})$ & $(\mathrm{B})$ & $(\mathrm{B})$ \\
25,0 & $15,6 \mathrm{~b}$ & $15,9 \mathrm{~b}$ & $12,8 \mathrm{a}$ & $15,5 \mathrm{~b}$ \\
& $(\mathrm{~A})$ & $(\mathrm{A})$ & $(\mathrm{A})$ & $(\mathrm{A})$ \\
\hline BNJ & \multicolumn{5}{c}{2,5} \\
\hline
\end{tabular}

Keterangan: Angka yang diikuti oleh huruf yang sama dalam satu kolom (huruf besar) dan baris (huruf kecil) tidak berbeda nyata berdasarkan uji BNJ pada $\alpha_{0,05}$. 
Tabel 6. Pengaruh kompos kulit buah kakao sebagai campuran pada media pembibitan dan pupuk NPK terhadap bobot basah akar tanaman kakao.

\begin{tabular}{ccccc}
\hline \multirow{2}{*}{$\%$ Kompos (v/v) } & \multicolumn{5}{c}{ Pupuk NPK (g/tanaman) } \\
\cline { 2 - 5 } & 1,5 & 3,0 & 4,5 & 6,0 \\
\hline 0,0 & $5,7 \mathrm{~b}$ & $5,2 \mathrm{ab}$ & $3,9 \mathrm{a}$ & $6,0 \mathrm{~b}$ \\
& $(\mathrm{~B})$ & $(\mathrm{B})$ & $(\mathrm{A})$ & $(\mathrm{B})$ \\
12,5 & $5,2 \mathrm{a}$ & $3,8 \mathrm{a}$ & $4,8 \mathrm{a}$ & $4,4 \mathrm{a}$ \\
& $(\mathrm{AB})$ & $(\mathrm{AB})$ & $(\mathrm{A})$ & $(\mathrm{AB})$ \\
25,0 & $3,7 \mathrm{a}$ & $3,2 \mathrm{a}$ & $3,1 \mathrm{a}$ & $3,3 \mathrm{a}$ \\
& $(\mathrm{A})$ & $(\mathrm{A})$ & $(\mathrm{A})$ & $(\mathrm{A})$ \\
\hline BNJ & & & 1,7
\end{tabular}

Keterangan: Angka yang diikuti oleh huruf yang sama dalam satu kolom (huruf besar) dan baris (huruf kecil) tidak berbeda nyata berdasarkan uji BNJ pada $\alpha_{0,05}$.

Tabel 7. Uji korelasi bobot kering akar dan kandungan zat hijau daun dengan tinggi tanaman, jumlah daun, diameter batang, dan bobot kering tajuk.

\begin{tabular}{lcccccc}
\hline \multicolumn{1}{c}{ Variabel } & $\begin{array}{c}\text { Tinggi } \\
\text { tanaman }\end{array}$ & $\begin{array}{c}\text { Jumlah } \\
\text { daun }\end{array}$ & $\begin{array}{c}\text { Diameter } \\
\text { batang }\end{array}$ & $\begin{array}{c}\text { Bobot } \\
\text { kering tajuk }\end{array}$ & $\begin{array}{c}\text { Bobot } \\
\text { kering akar }\end{array}$ & $\begin{array}{c}\text { Kandungan zat } \\
\text { hijau daun }\end{array}$ \\
\hline Kandungan zat hijau daun & $0,67^{* *}$ & $0,55^{* *}$ & $0,41^{*}$ & $0,64^{* *}$ & $0,40^{*}$ & - \\
Bobot Kering Akar & $0,61^{* *}$ & $0,49^{* *}$ & $0,62^{* *}$ & $0,75^{* *}$ & - & $0,40^{*}$ \\
\hline
\end{tabular}

Keterangan: * = nyata pada $\alpha_{0,05}{ }^{* *}=$ nyata pada $\alpha_{0,01}$.

selulase, poligalakturonase, pepsin, proteinase, dehidrogenase, dan derkaboksilase. Tanin bersifat antagonis terhadap hormon giberelin pada kecambah Pisum sativus. Selain menghambat aktivitas enzim, tanin juga menghambat kerja hormon dalam tanaman.

Menurut Harjadi (1979), hormon auksin merupakan hormon yang mempengaruhi diferensiasi tanaman yang ditunjukkan dengan pembentukan akar tanaman. Adanya kandungan senyawa tanin dalam kompos kulit buah kakao dapat menghambat kerja hormon auksin yang berperan dalam pembentukan akar tanaman. Akar tanaman berfungsi menyerap nutrisi di media tanam dan juga sebagai jalan masuk nutrisi dari dalam media tanam ke tanaman, termasuk senyawa tanin yang dapat diserap oleh akar. Adanya jaringan xylem yang dapat mengangkut air dan nutrisi dari akar mengakibatkan senyawa tanin ikut ditranslokasikan ke bagian organ tanaman lainnya. Salah satu organ tanaman yang terganggu yaitu daun.

Wattimena (1988) yang dikutip oleh Srilillah (2008) menyatakan bahwa giberelin mempunyai peranan fisiologis dalam memperbesar luas daun dari berbagai jenis tanaman dan dapat merangsang pembentukan enzim amilase di daun. Enzim ini berperan memecah senyawa amilum menjadi senyawa glukosa yang merupakan sumber energi pertumbuhan. Tanin dapat menghambat proses pembentukan glukosa di daun sehingga mengakibatkan berkurangnya energi bagi pertumbuhan organ tanaman lainnya termasuk akar. Jika pertumbuhan akar tanaman terganggu maka pertumbuhan tanaman akan terganggu. Hal ini didukung dengan adanya korelasi positif antara bobot kering akar dengan semua variabel pengamatan yang lainnya. Selain akar, kandungan zat hijau daun juga berperan dalam menghasilkan energi yang dibutuhkan pertumbuhan tanaman. Jika tanaman kekurangan energi maka pertumbuhan tanaman pun akan menurun. Hal ini juga didukung dengan adanya korelasi positif antara kandungan zat hijau daun dengan variabel pengamatan yang lainnya.

Upaya yang dilakukan agar kandungan senyawa tanin yang ada di kompos kulit buah kakao dapat dikurangi yaitu dengan perendaman kulit buah kakao terlebih dahulu. Kristijono (2010) menyatakan bahwa cocopeat (sabut kelapa) yang mengandung senyawa tanin sebelum dijadikan media tanam direndam atau direbus terlebih dahulu sampai warna merah batacokelat yang keluar benar-benar berkurang. 
Pada saat umur tanaman $2 \mathrm{~s} / \mathrm{d} 4$ BST peningkatan dosis pupuk NPK tidak berpengaruh nyata pada tinggi tanaman. Peningkatan dosis pupuk NPK juga tidak meningkatkan jumlah daun, bobot kering tajuk dan bobot kering akar pada bibit tanaman kakao. Hal ini diduga disebabkan bibit tanaman kakao hanya menyerap unsur hara sesuai yang dibutuhkan. Asumsi ini diperkuat oleh temuan Mayasari (2012) bahwa pemupukan secara berlebihan tidak serta merta menghasilkan pertumbuhan dan produksi yang baik karena unsur hara tidak semuanya diserap oleh tanaman.

Pemberian dosis pupuk NPK sebanyak 1,5 g/ tanaman telah mencukupi unsur hara yang diserap oleh akar bibit tanaman kakao. Jika pemberian dosis pupuk NPK ditingkatkan maka terjadi penurunan bobot kering akar tanaman kakao. Peningkatan dosis pupuk NPK dapat menurunkan $\mathrm{pH}$, media tanam menjadi bersifat asam akibat adanya proses nitrifikasi. Menurut Yuniasari (2009), bakteri nitrifikasi berperan mengubah $\mathrm{NH}_{4}^{+}$ (amonium) menjadi $\mathrm{NO}_{3}^{-}$(nitrat) menghasilkan ion $\mathrm{H}^{+}$ yang dapat membuat $\mathrm{pH}$ pada media tumbuh turun. Hal ini mengakibatkan unsur hara baik makro dan mikro tidak tersedia bagi tanaman sehingga nutrisi yang diserap oleh akar tanaman pun akan menurun.

Kombinasi perlakuan kompos $0 \%$ (v/v) dan pupuk NPK 1,5; 3,0; dan 6,0 g/tanaman menghasilkan ratarata dan bobot basah akar tertinggi. Jika dosis kompos ditingkatkan menjadi $12,5 \%$ (v/v) dan 25,0\% (v/v) maka terjadi penurunan dosis pupuk NPK yang menghasilkan bobot basah akar yang tidak berbeda nyata.

\section{KESIMPULAN}

Berdasarkan hasil penelitian yang telah dilakukan maka dapat disimpulkan bahwaPerlakuan tanpa kompos kulit buah kakao dalam media tanam menghasilkan pertumbuhan bibit tanaman kakao terbaik namun tidak berbeda nyata dengan campuran kompos kulit buah kakao sebanyak 12,5\% (v/v). Pemupukan NPK pada media tanam sebanyak 1,5 g/tanaman menghasilkan pertumbuhan bibit tanaman kakao terbaik. Pemberian dosis pupuk NPK sebanyak 1,5 g/tanaman, 3,0 g/ tanaman, dan $6,0 \mathrm{~g} /$ tanaman yang dikombinasikan dengan kompos $0 \%(\mathrm{v} / \mathrm{v})$ menghasilkan pertumbuhan bibit tanaman kakao terbaik.

\section{DAFTAR PUSTAKA}

Didiek, H.G. dan Y. Away. 2004. Orgadek,Aktivator Pengomposan. Pengembangan Hasil Penelitian Unit Penelitian Bioteknologi Perkebunan. Bogor. $87 \mathrm{hlm}$.
Harjadi, 1979. Pengantar Agronomi. PT Gramedia. Jakarta. $184 \mathrm{hlm}$.

Kristijono, A. 2010. Pemanfaatan gambut sebagai media tumbuh bituman (biji tumbuh mandiri) dalam rangka mendukung kegiatan rehabilitasi lahan kritis. Laporan Akhir. Badan Pengkajian dan Penerapan Teknologi. Jakarta. $87 \mathrm{hlm}$.

Mayasari, F. 2012. Pengaruh kombinasi bokashi pupuk kandang ayam, sapi dan pupuk NPK (15:15:15) pada pertumbuhan dan produksi tanaman tomat (Lycopersicum esculentum Mill.). Skripsi. Fakultas Pertanian Universitas Lampung. Bandar Lampung. $83 \mathrm{hlm}$.

Mensah, C.A., N.A. Adamafio, K. Amaning-Kwarteng and F.K. Rodrigues. 2012. Reduced tannin content of laccase-treated cacao (Theobroma cacao) pod husk. J. Biol.Chem. 1(6):1-6.

Pramiadi, D dan Suyitno. 2010. Uji daya alelopati ekstrak daun kleresede (Gliricidia sp.) melalui bioassay perkecambahan dengan biji sawi (Brassica sp.) dan biji bayam (Amaranthus sp.). Makalah. Fakultas Matematika dan Ilmu Pengetahuan Alam, Universitas Negeri Yogyakarta. Yogyakarta. $16 \mathrm{hlm}$.

Spillane, J. 1995. Komoditi Kakao, Peranannya dalam Perekonomian Indonesia. Kanisius. Yogyakarta. $380 \mathrm{hlm}$.

Srilillah, A. 2008. Pengaruh cara panen dan pemberian giberelin terhadap mutu buah dan pertumbuhan trubus baru manggis (Garcinia mangostana L.). Skripsi. Departemen Agronomi dan Hortikultura Fakultas Pertanian Institut Pertanian Bogor. Bogor. $41 \mathrm{hlm}$.

Sutejo, M. 2002. Pupuk dan Cara Pemupukan. Rineka Cipta. Jakarta. 125 hlm.

Yuniasari, D. 2009. Pengaruh Pemberian Bakteri Nitrifikasi dan Denitrifikasi serta Molase dengan C/N Rasio Berbeda terhadap Profil Kualitas Air, Kelangsungan Hidup dan Pertumbuhan Udang Vename (Litopenaeus vannamei). Skripsi. Departemen Budidaya Perairan Fakultas Perikanan dan Ilmu Kelautan Institut Pertanian Bogor. Bogor. 78 hlm. 